\title{
MODOS DE LER, MODOS DE SER: EXPERIÊNCIAS DE LEITURA E VIVÊNCIAS SOCIAIS
}

\section{Lucianne Michelle de}

Menezes* *lumy@hotmail.com

Doutoranda em Literatura Comparada (Universidade Federal Fluminense).
RESUMO: Este artigo apresenta e discute um comportamento feminino de leitura, mediante análise da personagem Luísa, de $O$ primo Basílio (Eça de Queirós). Enfoca-se o modo pelo qual ela absorve o padrão feminino culturalmente estabelecido à época, observando a maneira como isso se reflete na sua experiência de leitura, no seu posicionamento diante do que lê. No período em que o gênero romanesco se afirmava socialmente, a leitura feminina associava-se a um estereótipo de romantismo e distanciamento crítico, revelando assim a total inércia social intelectual imposta à mulher. Nesse sentido, é apresentado um contraponto entre as experiências da mulher nas estruturas sociais e familiares e suas experiências como leitora, tomando como base a atuação da protagonista da referida narrativa queirosiana.

PALAVRAS-CHAVE: leitura; perfil social; literatura.
ABSTRACT: This article presents and discusses a feminine reading behavior through examination of the character Luísa, from $O$ primo Basílio (Eça de Queirós). The article focuses on the way in which she absorbs the female behaviour culturally established at the time, and is observed how it reflects in her reading experience, her position on the readings. In the period in which the novelistic genre was socially affirmed, women reading was associated with a stereotype of romanticism and critcism avoidance, thus revealing the full social and intellectual inertia imposed on women. This way, it is presented a counterpoint between the experiences of women in social and family structures and their experiences as a reader, based on the actions of the protagonist of that queirosian narrative.

KEYWORDS: reading, social profile, literature. 
A leitura, especialmente de romances, na sociedade oitocentista, estabelecia-se como uma prática cultural feminina, o que denotava a condição de inferioridade atribuída à mulher pois tal gênero artístico, em certo período histórico, estava relacionado a um entretenimento fútil, permeado de emotividade, sem qualquer direcionamento crítico. Primeiramente, no período de seu surgimento (séc. XVIII), o gênero fora até mesmo recomendado pela crítica e pelos religiosos, por possuir um forte teor moralista e poder, dessa maneira, promover um processo de edificação moral, através da leitura; porém, quando o romantismo instaura-se e traz consigo fortes apelos sentimentais, emotivos, a forma romanesca passa a representar um veículo que poderia desvirtuar os princípios femininos; muito embora a narrativa romântica ainda continuasse a exaltar, comumente, o casamento e a vida afetiva como únicas possibilidades de realização da mulher. Tal situação dava-se porque não lhe era permitida uma atitude questionadora, de modo que ela pudesse enxergar, em algumas representações literárias, um padrão de comportamento feminino com o qual poderia não concordar, afinal, como coloca Culler (1999) "ambas as asserções são completamente plausíveis: que a literatura é o veículo de ideologia e que a literatura é um instrumento para sua anulação". ${ }^{1}$

O romance, aclamado no período de seu surgimento pelo forte teor moralista que possuía, foi mais tarde, à medida que se desenvolvia, considerado uma influência nociva para as senhoras da época. Abreu (2007), comentando a opinião de censores do século XIX, relata que eles consideravam que a leitura romanesca parecia ameaçar as instituições mais essenciais, como a família e a religião. A leitura de romances, a partir desse século, enfatizava um estereótipo de romantismo atrelado à mulher e muitas vezes essa prática foi considerada um hábito pernicioso, que poderia corromper as suas virtudes. Acreditava-se que através dos livros ela se desligava do "mundo real", poderia entregar-se à fantasia, a aventuras e a cenas emotivas que comprometiam os seus papéis de mãe e esposa. Não era questionado se tais papéis satisfaziam a mulher, se eram realmente esses os seus propósitos de vida simplesmente suas atuações sociais já estavam definidas e, consequentemente, de modo bastante restrito, uma vez que era sempre uma mente masculina que as determinava.

A leitura de romances, portanto, poderia representar um meio de a mulher ter acesso a outras formas de comportamento e de pensamento que porventura destoassem da sua realidade mais próxima; nesse sentido, a literatura marcava um veículo de expansão do universo feminino e isto poderia não ser recomendável às senhoras de então, que deveriam continuar exercendo sempre as mesmas atribuições sociais. Por outro lado, nota-se que essa leitura literária mesmo apresentando à mulher novas possibilidades de percepção, 
2. CULLER. Teoria literária: uma introdução, p. 45 ainda assim trazia, quase sempre, como marca feminina a realização pessoal pelo casamento, pela via amorosa, tendo uma presença masculina a direcionando. Desse modo, as mulheres manter-se-iam absolutamente dependentes, limitadas a um tipo de vida que não lhes permitia agirem por si mesmas, desenvolvendo as próprias convicções. E isto se manifestava no seu comportamento de leitura, muitas vezes sem nenhuma visão crítica, pois esta poderia fazê-la questionar o seu modo de vida.

A literatura representa, por exemplo, de uma maneira potencialmente intensa e tocante, o arco estreito de opções historicamente oferecidas às mulheres e, ao tornar isso visível, levanta a possibilidade de não se aceitar isso sem discussão. ${ }^{2}$

Para discutir, seria necessário que a mulher percebesse estreiteza de seu universo e que também tivesse condições de dar vazão à sua voz, porém, seria bastante difícil romper com um modelo social já instituído e fortalecido. Além disso, ela precisaria enxergar a literatura como um veículo que promove a reflexão, podendo, inclusive, alargar a percepção; todavia todo um contexto sociocultural impedia tal mudança.

Da Cal (1969: 50-53) salienta que o estilo literário do escritor português vai muito além da expressividade verbal, as palavras seriam um mecanismo através do qual, de maneira implícita, faz-se presente a sua concepção subjetiva do mundo e sua maneira particular de transformá-lo, adaptando-o a sua percepção. Segundo Belline (1997: 522-526), Eça de Queirós, com suas considerações críticas, mostra-se à frente de seu tempo, antecipando as teorias feministas que ressaltam como os processos sociais e psíquicos contribuem para perpetuar as desigualdades de gênero, envolvendo inclusive as criações literárias, afinal, estas se relacionam estreitamente com os aspectos socioculturais. Culler (1997: 52-60) afirma que a crítica feminista já considerou a ideia de continuidade entre as experiências da mulher nas estruturas sociais e familiares e suas experiências como leitoras, pertençam estas à ficção literária ou não. Nota-se, portanto, que a percepção e os papéis sociais femininos podiam conduzir a mulher a realizar uma leitura condicionada aos padrões impostos que muitas vezes a inferiorizavam. Observa-se, portanto, que essa limitação a que a mulher estava submetida determinava o modo como ela lia - com pleno envolvimento e identificação, sem o devido distanciamento crítico - como também marcava o que era lido - comumente romances que estavam associados a romantismo, devaneios, escapismo.

A própria ficção representa bem essa particularidade da leitura feminina, conforme já observado no capítulo anterior, na referência à obra do realismo francês - Madame Bovary - em que a personagem Ema desvincula-se de sua rotina tediosa, através dos romances que lê e passa a buscar 
emoções românticas, rompendo com normas sociais que lhe eram impostas. Verifica-se também na narrativa do realismo português de Eça de Queirós - O primo Baślio - uma temática semelhante que ressalta o envolvimento da literatura com aspectos sociais, enfatizando, inclusive, os efeitos da recepção literária e sua relação com uma possível função social: o distanciamento crítico, ausente tanto na representação feminina francesa quanto na portuguesa, pois, as obras expõem a participação social da mulher restrita aos "deveres" do casamento, em consonância com os valores burgueses, severamente condenados na estética realista.

Luísa, a protagonista queirosiana, é apresentada no início da narrativa numa situação de leitura e esta terá grande contribuição na caracterização dessa personagem. A figura do marido - Jorge - também surge no enredo numa cena de leitura e é significativa a diferença entre as obras que os dois leem; as preferências de cada um sugerem nitidamente um perfil psicológico e o papel social correspondente. Jorge interessa-se por leituras informativas, com temas sobre economia, por exemplo. Já Luísa, além do Diário de Notícias, é leitora assídua de romances, a exemplo de A dama das camé lias, de Alexandre Dumas Filho, cuja trama exibe um intenso sentimentalismo. Tal caracterização já demonstra que as atividades masculinas eram sempre consideradas úteis, relevantes, já a mulher via na leitura um meio de vencer a apatia de uma rotina tediosa.
Para Culler (1997: 70), foi criada uma oposição entre o masculino e o feminino, de modo que a cada universo equivale respectivamente a oposição racional/emocional, sério/ frívolo. Luísa representava a feminilidade absolutamente emotiva e fútil. Faltava a ela uma experiência de vida e um modo de leitura, consequentemente, que lhe permitissem criar uma identidade que não se orientasse por normas pré-estabelecidas.

Até o reencontro com o seu primo Basílio - um amor de juventude - percebe-se que Luísa levava uma vida extremamente tranquila, que tendia à ociosidade. Como era natural entre as senhoras da sua classe, ela possuía duas criadas em casa e passava os dias vivendo ao redor do marido; preenchendo as horas, em que ele se ausentava para o trabalho, com a leitura de romances românticos e a execução de músicas ao piano - uma rotina tediosa e preguiçosa, que revela a superficialidade dessa personagem. Ao mesmo tempo em que tais hábitos eram cultivados por ela mesma, eram também impostos pelas normas sociais vigentes:

Luísa espreguiçou-se. Que seca ter que ir se vestir! Desejaria estar numa banheira de mármore cor-de-rosa, em água tépida, perfumada, e adormecer! Ou numa rede de seda com as janelas cerradas, embalar-se, ouvindo música! Sacudiu a chinelinha; esteve a olhar muito amorosamente o seu pé pequeno, branco como leite, com veias azuis, pensando numa infinidade de 
3. QUEIRÓS. O primo Basilio, p. 20.

\section{QUEIRÓs. Uma campanha} alegre, p. 115.

5. QUEIRÓs. 0 primo Basílio, p. 88 coisinhas: - em meias de seda que queria comprar, no farnel que faria a Jorge para a jornada, em três guardanapos que a lavadeira perdera. ${ }^{3}$

As preocupações que compõem o universo da personagem limitavam-se a questões irrelevantes, banais e a leitura é mais uma estratégia para preencher o vazio da sua rotina e driblar a passagem lenta das horas, não é um exercício que estimula o seu raciocínio. É válido destacar que a ociosidade observada no seu cotidiano revela a perspectiva crítica de Eça que, desde a escrita de As Farpas, já censurava a nula participação social da mulher que, impedida de envolver-se em obrigações e deveres associados, por exemplo, a uma carreira profissional, vive, naquela época, imersa em um tédio limitador e "vai puxando o tempo pelas orelhas, derreada com sua ociosidade, e bocejando as horas". ${ }^{4}$ Esse é o retrato do dia-a-dia da personagem Luísa que oscila entre ficar "ora estendida na causense lendo aos bocados, ora batendo distraidamente no piano pedaços de valsas". ${ }^{5}$ A leitura, nesse contexto, atua como uma atividade aplacadora do tédio, transportando a personagem para um mundo fantasioso, mais atrativo que o seu.

Outro ponto que revela a limitação do universo de Luísa é a subserviência ao marido. As suas amizades têm que ser autorizadas por Jorge, que permite apenas que frequentem a casa os amigos comuns ao casal, cuja reputação é aceitável socialmente. Ele proíbe o contato da esposa com uma amiga de infância, pois vê na aproximação delas uma influência nociva para a sua mulher. "Tudo, menos a Leopoldina". ${ }^{6}$ A partir da expressão do marido de Luísa, já se pode perceber que essa mulher recebia forte censura. Numa sociedade com leis rígidas aplicadas ao comportamento feminino, a não obediência às normas de conduta acarretava a condenação social. A mulher transgressora era alvo de críticas e de comentários maldosos, o simples fato de ser vista em uma residência familiar, poderia comprometer a moral dos que compunham aquele lar. Isso explica a irritação de Jorge ao saber que Luísa consentira a visita de Leopoldina e justificava a sua ordem de não deixá-la entrar em casa: “-É por causa de ti! É por causa dos vizinhos! É por causa da decência!”?

É válido destacar que a medida da moral burguesa dava-se com base na opinião dos vizinhos, estes eram os responsáveis pela emissão de juízos de valor a respeito da dignidade e honradez de um núcleo familiar. A meta burguesa era a manutenção das aparências, da reputação, e para conservá-las fazia-se necessário fugir do alvo crítico da vizinhança.

Jorge, ciente de que precisaria viajar para resolver questões de trabalho (tipicamente masculinas), faz recomen dações ao amigo Sebastião, pedindo-lhe que passe a zelar por Luísa enquanto ele estiver fora. A figura masculina definia as diretrizes que a mulher deveria seguir e, nesse caso, como
EM TESE
BELO HORIZONTE
v. 19
N. 3
SET.-DEz. 2013 MENEZES. Modos de ler, modos de ser [...]
P. $159-177$

7. QUEIRÓS. O primo Basílio, p. 30 . 
8. QUEIRÓS. O primo Basilio, p. 43

9. QUEIRÓs. O primo Basílio, p. 58 o marido - responsável direto pela condução do comportamento da esposa - estaria ausente, a incumbência da "vigília" é designada ao amigo íntimo. As precauções tomadas por Jorge buscam evitar o contato da esposa com a sua antiga amiga, uma vez que ela é "uma criatura que tem mais amantes que camisas [...]".

Com a partida de Jorge, Luísa se vê entregue a um tédio ainda maior, pois ela não tem, nesse período, a obrigação de ocupar-se de certos cuidados para com ele e a leitura de romances torna-se mais claramente um dos mecanismos para vencer o tédio e a angústia advinda disso: "estava tão farta de estar só! Aborrecia-se tanto! De manhã, ainda tinha os arranjos, a costura, a toilette, algum romance... Mas de tarde!”. $O$ fato de não ter filhos também contribui para essa situação, afinal, os cuidados exigidos por eles, ocupariam os seus dias, numa perfeita adequação ao modelo feminino burguês de esposa e mãe.

Com relação à estética queirosiana, Da Cal (1969: 81-85) ressalta que o vocabulário utilizado no texto tem uma intenção objetiva, a serviço de uma visão de mundo e, desse modo, o léxico comum não é arrancado de seu uso convencional, ainda assim parece impregnar-se de um novo teor permitindo uma série de associações e reflexos significativos. Com base nisso, nota-se que a caracterização, inclusive física, de Luísa favorece uma reprodução plástica de uma natureza moral - o uso de diminutivos confere à personagem uma certa fragilidade, aliada à dependência, à fraqueza. A partir da fugacidade de atitudes momentâneas, Eça consegue plasmar elementos psicológicos. "Era asseada, alegre como um passarinho"; "Um sorriso vagaroso dilatou-lhe os beicinhos"; "pasmada, saboreando, com um arzinho beato". ${ }^{10}$

Com a chegada de Basílio a Lisboa, voltam à mente de Luísa lembranças do namoro de ambos outrora. E o modo como ele a olhava desperta sua vaidade, principalmente porque ele agora é um homem rico e conhecia vários lugares do mundo em viagens que fizera. Sentir-se desejada, por um homem assim, trazia-lhe genuína satisfação. Dantas (1999: 93-96) salienta que a chegada do primo e antigo namorado veio conferir, à vida dela, um grau de excepcionalidade; segundo o autor, está em jogo o amor próprio que a paixão por Basílio lhe instiga. Sentir-se alvo do interesse de um homem do porte de Basílio tornava-a mais importante, seu orgulho era ainda maior do que ser apenas a "esposa de Jorge". Nessas circunstâncias, ela se vê impedida de recusá-lo, mostrando-se "impressionável, passiva, inconsistente, fraca e amoldável, enfim um verdadeiro fantoche". ${ }^{11}$

Machado de Assis (1962), ao criticar o romance O primo Basílio, não atribui a passividade apenas à Luísa; para ele a consciência do autor se sobrepõe às motivações internas dos personagens, como fator determinante nas sequências
10. QUEIRÓS. O primo Basílio, p. 17, 21 e 26 (grifos meus).

11. DANTAS. $A$ mulher no romance de Eça de Queirós, p. 96.
EM TESE

BELO HORIZONTE

v. 19

N. 3

SET.-DEZ. 2013

MENEZES. Modos de ler, modos de ser [...]

P. $159-177$ 
narrativas. Eles lhe parecem títeres, matéria inerte. Mas, na visão de Dantas (1999: 97-100), a superficialidade é característica típica de Luísa, afinal, são os sentimentos de Basílio que lhe confirmam a sua beleza, sedução e superioridade. Desse modo, conclui-se que ela adquire autoestima através do que julga despertar no outro. Sua concepção a respeito de si mesma é estabelecida através da perspectiva alheia.

O primo inspira em Luísa o tipo de vida que ela gostaria de ter, além de despertar também a possibilidade de uma vivência amorosa que ela sonhara experimentar e que só conhecia por meio dos romances que lia. Para Dal Farra (2004: p. 6-9), a atuação de Luísa, ao longo da narrativa, se deve a um tipo de formação burguesa aliada a um comportamento de leitura, ou seja, uma vez que ela absorvia certos clichês românticos, advindos das obras lidas, tornava-se "presa fácil" nas mãos de Basílio. Este seu primo parece emergir do universo fictício que tanto a agradava: era um homem rico, elegante, conhecia vários lugares do mundo, aos quais ela só tinha acesso através dos romances. Até mesmo a traição conjugal era-lhe apresentada de modo idealizado, como se ele estivesse delineando uma narrativa que a impressionava e atraía:

Depois falou muito de Paris; contou-lhe a moderna crônica amorosa, anedotas, paixões chics. Tudo se passava com duquesas, princesas, de um modo dramático e sensibilizador, às ve- zes jovial, sempre cheio de delícias. E, de todas as mulheres de que falava, dizia recostando-se: era uma mulher distintíssima; tinha naturalmente o seu amante...

O adultério aparecia assim um dever aristocrático. De resto a virtude parecia ser, pelo que ele contava, o defeito de um espírito pequeno, ou a ocupação reles de um temperamento burguês. ${ }^{12}$

O poder de influência de Basílio era habilmente utilizado, uma vez que ele sabia como despertar a vaidade da prima, sendo galanteador, fazendo-a sentir-se desejada, irresistível. E isto se aliava ao fato de ele, também muito vaidoso, mostrar-se sempre superior às pessoas que se relacionavam com Luísa, de modo que ela passasse a julgar como um verdadeiro privilégio a convivência com esse primo, tão elegante e viajado. $\mathrm{E}$, além disso, o fato de perceber o interesse dele, aparentemente afetivo, fazia-a supor que também ela era uma criatura esplendorosa. Assim, combinavam-se Basílio e Luísa, por um defeito comum a ambos: a excessiva vaidade. Ele, sendo extremamente pretensioso, iludia a prima, com elogios, promessas amorosas, e ela, por sua vez, comprazia-se por julgar-se bela, atraente. Tal aspecto é percebido principalmente na maneira como Luísa lê as cartas que Basílio lhe envia, a sua vaidade e autoestima são despertadas a partir de juras de amor e galanteios lidos no texto do primo. 
13. QUEIRÓS. O primo Basílio, p. 134.

14. QUEIRÓs. $O$ primo Basílio, p. 26
Tinha suspirado, tinha beijado o papel devotamente! Era a primeira vez que lhe escreviam aquelas sentimentalidades, e o seu orgulho dilatava-se ao calor amoroso que saía delas, como um corpo ressequido que se estira num banho tépido; sentia um acréscimo de estima por si mesma e parecia-lhe que entrava enfim numa existência superiormente interessante [...]. ${ }^{13}$

Mas Basílio não era a única personalidade a influenciar Luísa. Leopoldina também despertava a sua admiração, tinha a coragem e a descontração que lhe faltavam, gozava vida com uma certa liberdade, escolhia os homens com quem queria se relacionar, vestia-se de modo sedutor, fumava, enfim, não seguia o padrão recatado da senhora casada, muito embora estivesse subordinada também a um matrimônio. A vida dessa mulher parecia a Luísa muito atrativa, assim como a rotina de Basílio, com suas viagens e fatos excepcionais. Leopoldina para ela era como a "versão feminina" de seu primo, ousada e irreverente, de modo que ela considerava-a "uma heroína, e olhava-a com espanto como se consideram os que chegam de alguma viagem maravilhosa e difícil, de episódios excitantes" ${ }^{14}$ Assim como Basílio lembrava a Luísa o herói dos romances que ela lia, Leopoldina também era admirada por parecer-lhe uma personagem de ficção, pois vivenciava aventuras, tinha uma rotina agitada. Luísa, circunscrita ao cotidiano doméstico, projetava em Leopoldina a personificação de uma heroína romântica, não exatamente pelos amantes que possuía, mas sim pelo fato de a vida da amiga ser mais intensa e prazerosa que a sua. Através dessa mulher, Luísa mais uma vez transferia referências de suas leituras para a sua vida prática, projetando-a para além da realidade.

Porém, Leopoldina havia feito um casamento infeliz e buscava nos relacionamentos extraconjugais a satisfação afetiva que ainda não encontrara. É significativa a cena em que confidencia a Luísa que está apaixonada por um poeta, revelando todo o teor romântico de sua índole, tão desprestigiada socialmente. $\mathrm{O}$ fato de o rapaz ser um poeta conferia-lhe um importante diferencial, na visão de Leopoldina, muito embora o narrador queirosiano afirmasse que a poesia por ele criada era "uma composição delambida, de um sentimentalismo reles, com um ar tísico, muito lisboeta, cheia de versos errados". ${ }^{15}$ Mais uma vez a ironia de Eça de Queirós se sobrepõe ao texto, numa severa crítica ao romantismo, pois até mesmo os caracteres físicos citados nessa passagem da narrativa, confundem-se com as informações reais acerca de alguns poetas românticos. Eça também condena a acentuada emotividade, típica do perfil feminino da época e que tanto contribuía, na visão do escritor, para a sua estreiteza intelectual. À Luísa agradavam os romances comoventes e sentimentais, Leopoldina também suspirava diante de um poema construído sob temáticas amorosas e a visão de mundo de 
ambas se constituía embasada apenas em preocupações de cunho emocional; à mulher não cabiam reflexões de ordem social, financeira, científica, entre outras afins. $\mathrm{O}$ romance queirosiano denuncia tal limitação mediante representações femininas bastante verossímeis, considerando o contexto do século XIX; a trama confirma também como a presença masculina marcava as principais atitudes e vivências da mulher, comumente envolvida em assuntos afetivos, reforçados na leitura que realizava.

O envolvimento entre Luísa e o seu primo vem confirmar um discurso moral típico da época em que a sociedade burguesa encontrava-se em plena ascensão. Cabia ao homem especialmente o solteiro, como Basílio - um comportamento sedutor, de modo a criar sempre uma oportunidade em que pudesse desfrutar de uma situação. Já a mulher, caso se submetesse a uma aventura amorosa fora dos padrões morais vigentes, condenava-se socialmente, expunha-se ao risco do repúdio das pessoas. Porém, para Luísa, o encanto da aventura e a chance de experimentar o novo, quebrando a rotina tão previsível que sempre tivera, fascinavam-na a ponto de fazê-la, naquele momento, ignorar as circunstâncias.

Segundo Duarte (1997: 352-354), Basílio representava para Luísa a oportunidade de evoluir de mera leitora a protagonista, ou seja, os enredos amorosos não seriam apenas lidos, mas vivenciados de fato, com toda a atmosfera típica dos romances; logicamente estes não exaltavam a traição, mas representavam histórias permeadas de sentimentalismo e suas respectivas digressões. Luísa não possuía astúcia suficiente para compreender que, envolvida na temática amorosa, estava a ideologia burguesa do casamento e/ou da realização da mulher limitada ao viés afetivo. Na sua projeção, ela fantasiava elementos que poderiam ser encontrados numa narrativa romanesca: um amor ilícito, encontros fortuitos, às escondidas, um amor entre primos, que sobreviveu ao tempo, um reencontro da juventude... "uma curiosidade intensa, múltipla, impelia-a, aquela aventura que lera tantas vezes nos romances amorosos! Era uma forma nova do amor que ia experimentar, sensações excepcionais!” ${ }^{16}$ Evidencia-se, desse modo, que a leitura literária realizada pela protagonista era uma marca de influência no seu comportamento, direcionava suas atitudes, numa intensa fusão entre ficção e realidade.

É válido destacar que essa falta de discernimento entre a fantasia e a vida real é uma característica mais evidente em Luísa. A sua amiga Leopoldina, embora também vivesse sob a atmosfera restrita do mundo feminino da época e se ocupasse com futilidades e sentimentalismos, conseguia enxergar a desigualdade social que distinguia homens e mulheres, por isso passava a desejar para si a liberdade concedida somente à figura masculina: "- Os homens são bem mais felizes que nós! Eu nasci para homem! O que eu faria!". ${ }^{7}$
16. QUEIRÓS. O primo Basílio, p. 145. 
As concepcões de Leopoldina tornavam-na uma mulher à frente de seu tempo. A liberdade que desejava para si só era permitida à figura masculina, porém, ela via nisso um desajuste cultural e o meio que encontrava para driblar tal circunstância era a transgressão, preferia desafiar a moral dominante a curvar-se ao cárcere da submissão. Leopoldina buscava, portanto, dentro de suas possibilidades, satisfazer-se, contrariando, naquilo que podia, o código de conduta da mulher burguesa. Sua transgressão, diferentemente daquela observada em Luísa, deveu-se a uma incompatibilidade de valores, de modelos sociais com os quais ela não concordava. E para sustentar tal concepção, rompia drasticamente com o papel feminino burguês, inclusive no tocante à maternidade como incumbência a ser acatada por toda mulher casada; é o que demonstra o diálogo a seguir entre as duas amigas:

- São tolices, no fim, andar, viajar! A única coisa neste mundo é a gente estar na sua casa, com o seu homem, um filho ou dois..

$$
\text { [...] }
$$

- Que horror! - exclamou com convicção. - O incômodo todo o tempo que se está!... as despesas! Os trabalhos, as doenças! Deus me livre! É uma prisão! [...] Uma mulher com filho está inútil para tudo, está atada de pés e mãos! Não há prazer na vida. É estar ali a aturá-los... Credo! $[\ldots]$
Luísa achava uma 'infâmia'. A outra encolheu os ombros, acrescentou:

- E depois, minha rica, é que uma mulher estraga-se; não há beleza de corpo que resista. Perde-se o melhor. ${ }^{18}$

A moral burguesa moldada nos valores familiares, delimitando para a figura feminina as atribuições de esposa e mãe, era natural para Luísa, pois ela não ousava contrariar, deliberadamente, a norma. Já Leopoldina, embora sofresse com o bombardeio público, preferia-o a manter-se refém de regras sociais que a tolhiam e incomodavam, afinal, "os deveres irritavam Leopoldina". ${ }^{19}$ Ao mesmo tempo em que se emocionava ao recordar episódios de $A$ dama das camélias junto com Luísa, aquela mulher não encontrava na leitura o seu veículo de fuga da realidade; era sentimental, mas não era tola, não admitia privar-se do que considerava bom e divertido em obediência a convenções sociais criadas à sua revelia.

Em Leopoldina, é possível perceber um perfil feminino transgressor por opção. Ela, diferentemente de Luísa, não se deixava conduzir por terceiros, escolhia o seu estilo de vida e assumia as consequências disso, era autêntica. E a crítica de Eça de Queirós atua no sentido de denunciar que as ações de Leopoldina, na verdade, eram as mesmas verificadas em outras senhoras casadas que, da mesma maneira
18. OUEIRÓS O primo Basílio, p. 126-7.

19. QUEIRÓs. O primo Basílio, p. 128. 
20. QUEIRÓS. O primo Basílio, p. 258

21. DANTAS. A mulher no romance de Eça de Queirós, p. 59.

22. QUEIRÓs. $O$ primo Basílio, p. 258. que ela, estavam "cansadas decerto de uma virtude monótona” ${ }^{20} \mathrm{~A}$ grande diferença era que as demais não assumiam o seu comportamento, dissimulavam-no. Afinal, "a psicologia burguesa privilegia a aparência, o que ostenta e exibe, ainda que não tenha nenhum fundamento real" (DANTAS, 1999 59). ${ }^{21}$ Tais senhoras, portanto, viviam totalmente envoltas no "escudo" da hipocrisia e assim conseguiam obter o respeito e a aceitação social, enquanto Leopoldina não possuía a "estima da corte"22 e não era bem vinda sequer na casa de sua amiga de infância. Sua presença poderia corromper a virtude atribuída à Luísa e ao seu lar, muito embora a protagonista venha a tornar-se também uma mulher transgressora, adúltera. Porém, em Luísa é muito mais exacerbada a influência das leituras românticas, estas norteavam as suas ações e sentimentos. E enquanto Leopoldina violava as normas de conduta social por opor-se a elas, Luísa as infringia pelo simples desejo de vivenciar uma aventura amorosa, trazendo para a sua realidade algo próximo daquela encontrada na ficção. Seu intuito não é a transgressão, embora também o faça, mas vivenciar episódios românticos semelhantes aos dos livros lidos. E ao lê-los a personagem realiza o que Chartier (1999) denomina "investimento afetivo" (p. 70), uma vez que ela se apropria de certas concepções encontradas nos romances.

É bastante significativa, nesse sentido, a expectativa de Luísa em conhecer o Paraíso, o lugar definido por Basílio para os encontros clandestinos de ambos. Extremamente influenciável e sonhadora, ela fantasiava encontrar um lugar semelhante àquele que lia nos romances - entremeado de detalhes românticos - como se isto fosse evidenciar que, para Basílio, era um grande privilégio recebê-la e, portanto, o local escolhido precisava condizer com os sentimentos que ela, em sua extrema vaidade, julgava despertar nele.

Mas era num terceiro andar, - quem sabe como seria lá dentro? Lembrava-lhe um romance de Paulo Féval em que um herói, poeta e duque, forra de cetins e tapeçarias o interior de uma choça; encontra ali a sua amante; os que passam, vendo aquele casebre arruinado, dão um pensamento compassivo à miséria que decerto o habita - enquanto dentro, muito secretamente, as flores se esfolham nos vasos de Sèvres e os pés nus pisam Gobelins veneráveis! Conhecia o gosto de Basílio, - e o Paraíso decerto era como no romance de Paulo Féval. ${ }^{23}$

Considerando a perspectiva de Jauss (1979), com relação a formas de recepção de textos literários, pode-se notar que a personagem queirosiana transformava as suas leituras em modelos de ação a serem seguidos. A expectativa de Luísa era a de concretizar as suas fantasias afetivas em um local idealizado, preparado para oferecer todo o conforto e requinte condizentes com heróis românticos, desse modo ela 
24. QUEIRÓS. O primo Basílio, p. 146.

25. QUEIRÓs. O primo Basílio, p. 146. estaria de fato protagonizando um enredo semelhante àqueles tantas vezes lidos:

Sentia uma sensação deliciosa em ser levada assim para o seu amante, e mesmo olhava com certo desdém os que passavam, no movimento da vida trivial - enquanto ela ia para uma hora tão romanesca da vida amorosa! ${ }^{24}$

Porém, foi grande o espanto da jovem senhora ao observar que se dava o oposto do que sonhara: o local decepcionou-a por ser pobre, sem nenhuma espécie de conforto e por levá-la a uma realidade que destoava consideravelmente dos seus ideais românticos. Não mais se sentia orgulhosa por vivenciar uma aventura amorosa, mas sim, naquele instante, a frustração a dominava. "Luísa viu logo, ao fundo, uma cama de ferro com uma colcha amarelada, feita de remendos juntos de chitas diferentes; e os lençóis grossos, de um branco encardido e mal lavado, estavam impudicamente entreabertos.... ${ }^{25}$ Os arredores do local também ironizavam o termo criado por Basílio quando se referia ao quarto. $\mathrm{Na}$ verdade tudo aquilo nada tinha de Paraíso. E Luísa mal podia disfarçar a tristeza que lhe causava a visão daquela realidade que denotava tanto desleixo e que, portanto, não poderia ser o cenário de sua romanesca aventura amorosa, afinal, era o contrário do que desejara. Contudo, a personagem, passado o pasmo inicial, acaba por aceitar encontrar-se com o primo mesmo naquelas condições, pois embora o local, escolhido por ele, contradissesse as expectativas que ela criara a partir de suas leituras, ainda assim, nesse momento da narrativa, Luísa admirava Basílio e via nele a possibilidade de realizar suas fantasias românticas, ampliando seus horizontes para além do que a vida burguesa e o Paraíso lhe ofereciam.

O despertar para uma árida realidade vem quando Luísa é chantageada pela criada Juliana, que tinha a posse de cartas reveladoras do adultério; a protagonista então resolve sugerir a Basílio que a leve consigo a Paris, criando uma situação de fuga bastante excitante - porque semelhante a cenas romanescas - e que ainda a libertaria de suas restritas condições de vida. Mudaria de país, conheceria novos lugares, não seria apenas uma simples senhora casada que vive nos limites de sua residência.

O que havia de infeliz em abandonar a sua vida estreita entre quatro paredes, passada a examinar róis de cozinha e a fazer crochê, e partir com um homem novo e amado, ir para Paris! Para Paris! Viver nas consolações do luxo, em alcovas de seda, com um camarote na ópera!... Era bem tola em se afligir! Quase fora uma felicidade aquele "desastre"! Sem ele nunca teria tido a coragem de se desembaraçar da sua vida burguesa [...]. ${ }^{26}$

Percebe-se que a própria Luísa tinha ciência de que sua rotina era limitadora e não condizia com suas aspirações, seus 
sonhos e suas vaidades. A fuga com Basílio representava a grande oportunidade de revolucionar a sua existência, traçando-a de acordo com sua vontade e, por mais que isso a assustasse, trazia-lhe motivação. Porém, o primo, ao mesmo tempo em que instiga o devaneio, parece ser a figura que transporta Luísa da fantasia para o mundo real. Ela já havia notado nele algumas atitudes que a desagradaram e frustraram e, no que se refere à fuga tão sonhada ao seu lado, é válido acrescentar que é justamente esse homem que a faz despertar para uma dura realidade: “- Estás doida, Luísa; tu não estás em ti! Pode lá pensar em fugir? Era um escândalo atroz [...] Fugir é bom nos romances!” ${ }^{27}$ Basílio estabelecia, nesse instante, o distanciamento entre a ficção romântica e a realidade; a sugestão de Luísa advinha, segundo ele, de uma criação utópica, sem serventia na vida prática, apenas no momento da leitura. E interessante perceber que o apelo à sensatez, nos moldes da moral burguesa, só é considerado por Basílio no instante em que isso lhe convém. Ao induzir Luísa à transgressão, ele desprezara as normas de conduta, considerando-as ultrapassadas entretanto, quando a prima lhe propõe uma solução que criaria um compromisso entre os dois, ele argumenta que a ideia contrariava os princípios vigentes. Vê-se na trama, portanto, uma severa crítica aos valores burgueses que só teriam importância de acordo com a conveniência.

Verifica-se também, a partir de $O$ primo Basílio, a denúncia a respeito das marcantes desigualdades sociais que delimitavam o comportamento masculino e o feminino. A própria Luísa passava a perceber que, naquele contexto, o homem apenas desfrutava da aventura amorosa "ilícita" e permanecia livre de graves acusações morais, como se tivesse cumprido o seu papel de conquistador, de sedutor, o que poderia até mesmo lhe render algum prestígio. A mulher, no entanto, passaria a viver como refém do seu próprio medo, atormentando-se com a possibilidade de a sua transgressão ser descoberta, afinal, isto causaria penosos danos à sua reputação, à sua posição social de mulher casada, que teria na virtude um dever moral. Luísa arrepende-se do adultério, se sujeita a todas as humilhações da criada para que esta não o revele, dessa forma não perderia, ao menos nas aparências, a sua "credencial" de senhora com virtude ilibada. A protagonista começava a enxergar que servira de mero objeto sexual ao primo e a sua condição de mulher, nessas circunstâncias, impunha-lhe o ônus do erro, do delito, enquanto para Basílio a alternativa mais viável era isentar-se da culpa, muito embora a experiência vivida tivesse sido partilhada entre os dois.

Enquanto ela fora a mulher alegre, que vem, despe o corpete mostra um lindo colo - então bem, pronto! Mas teve uma dificuldade, chorou, sofreu - ah! não, isso não! És um belo animal que me dás muito prazer - perfeitamente, tudo o que quiseres; mas tornas-te uma criatura dolorida que precisa de

EM TESE

BELO HORIZONTE

v. 19

N. 3

SET.-DEZ. 2013

MENEZES. Modos de ler, modos de ser [...] P. $159-177$ 
consolações, talvez uns poucos de centos de mil-réis - então boas noites, cá vou eu no paquete! Oh que estúpida que é a vida! (QUEIRÓS, 2004: 270). ${ }^{28}$

É nesse ponto da narrativa que Luísa torna-se ciente do caráter de Basílio e suas experiências de leitura servem-lhe agora como um veículo para novas divagações, imaginando outras direções que sua vida poderia ter tomado. Na perspectiva de Lajolo (1997:440-444), é central o papel que a leitura desempenha na composição de Luísa. É com base nessa sua prática que o narrador caracteriza diferentes estados de espírito da protagonista: a antiga leitora romântica de Walter Scott (1771 - 1832) sobrevive ainda na Luísa casada, adúltera e já vítima das chantagens da criada Juliana:

Que diferente sua vida teria sido - desta agora tão alvoroçada de cólera e tão carregada de pecado! [...] Onde estaria? Longe, nalgum mosteiro antigo, entre arvoredos escuros, num vale solitário e contemplativo; na Escócia, talvez, país que ela sempre amara desde as suas leituras de Walter Scott. ${ }^{29}$

Luísa, na verdade, havia se tornado refém da sua própria escrita, que continha informações comprometedoras. Ela redigira cartas, gênero textual que pressupõe privacidade e que normalmente é endereçada a um único sujeito. $O$ conteúdo do que se escreve, portanto, comumente fica restrito ao autor e ao receptor. Porém, como a correspondência de Luísa fora violada, sua escrita depõe contra ela própria, externando o quanto estava emocionalmente envolvida com o seu primo.

Com a súbita morte de Juliana, cessam as ameaças a Luísa, mas ela passa a sentir as consequências físicas de todo o tormento psicológico por que passara. É como se todas as inquietações e angústias ainda a mantivessem de pé, mas, quando se viu liberta das chantagens, entregou-se ao "cansaço moral" e sua saúde se torna bastante comprometida. $\mathrm{O}$ relacionamento ilícito era radicalmente avesso à ideia de pureza e subserviência impostas à mulher e com base nesse preceito, culturalmente instituído, Luísa agora se torna vítima de si mesma: da vergonha do que fizera, do remorso, do sentimento de culpa e do medo, especialmente quando Jorge vem a descobrir a traição que ela tanto penara para ocultar. Sua saúde, já abalada, vai-se extinguindo com uma intensidade surpreendente; é facilmente sucumbida pelos delírios, pela prostração. Seu caráter passivo é mais uma vez conduzido, só que nesta ocasião, pelo seu próprio sofrimento, este é o algoz que a domina e a leva à morte.

Convém ressaltar que Luísa absorvia o padrão de comportamento feminino socialmente imposto; embora ela tenha revelado um desejo de libertação ao transgredir a norma, ainda assim a cobrança íntima fez-se presente e a atormentou de maneira fatal. A obra queirosiana permite perceber que, muitas vezes, a própria mulher aceitava sua condição social e 
sofria por não se sentir capaz de cumprir as prerrogativas do perfil que the era imposto. E a leitura, no caso da personagem Luísa, era um recurso de que lançava mão para momentaneamente desprender-se do padrão a que estava atrelada, muito embora os romances lidos, de certo modo, ainda mantivessem aspectos desse perfil social. Além disso, a culpa e a morte acabam servindo-lhe como punição, o que denota certo moralismo na perspectiva do autor de O primo Baślio.

Para Sacramento (1945: 142-145), a ironia na obra de Eça não constitui uma "quebra" na sua estética realista, mas ao contrário, a tendência irônica impulsiona a sua narrativa, é-lhe peculiar. Uma das muitas passagens em que se percebe tal característica é o último capítulo, em que o narrador traz o necrológio que o conselheiro Acácio dedicara à Luísa, enfatizando suas virtudes: "Mais um anjo que subiu ao céu [...] Ali jaz a casta esposa tão cedo arrancada às carícias do seu talentoso cônjuge. Ali sobroçou [...] a virtuosa senhora [...]" ${ }^{30} \mathrm{O}$ substantivo "anjo", bem como os adjetivos "casta" e "virtuosa" evidenciam não apenas a ironia queirosiana, considerando as atitudes de Luísa, mas também o modelo social que estava estabelecido: atribui-se ao homem (neste caso, Jorge) qualificativos de teor prático e com relação à mulher esperava-se exatamente o que fora dito por Acácio - a virtude da pureza de corpo e de alma. E para alcançar estas qualidades, ela era muitas vezes impingida a negligenciar sua identidade, suas preferências e sonhos, evitando assim o repúdio público. Por outro lado, observa-se que o ideal de vida que Luísa sonhava para si não estava muito distante do molde burguês feminino, pois se fundamentava ainda na realização através do casamento, da vivência amorosa. Nas suas fantasias, reforçadas pelas leituras que constantemente fazia, ela se imaginava mais rica, vivendo possivelmente em Paris - que a atraía não por estar, na época, culturalmente à frente de Portugal, mas pelo luxo que lá possivelmente encontraria - e principalmente sonhava em vivenciar aventuras amorosas que destoassem da rotina de seu casamento, que fossem parecidas com aquelas descritas nos romances.

A leitura romanesca a fazia conhecer outros modos de vida, perspectivas diferentes que a atraíam, porém, na essência ainda a conduziam ao padrão burguês a ser cumprido, pois estava em jogo o modo como ela lia: sem qualquer reflexão crítica, apenas absorvendo episódios românticos e imaginando-se participando deles. A leitora Luísa não questionava a sua realidade, a partir do que lia, apenas transportava-se do mundo real para a fantasia. Ainda que a fuga com Basílio para Paris tivesse se concretizado, Luísa continuaria a realizar-se unicamente pelo viés amoroso e pela vida ainda mais confortável que tal relacionamento lhe proporcionaria. Sua participação social e sua perspectiva crítica permaneceriam anuladas. 
31. CULLER. Sobre a desconstrução - teoria e crítica do pós-
estruturalismo, p. 60 .
A protagonista destaca-se pela passividade, o que a torna fútil, omissa, sem nenhuma atitude enérgica que promova o seu estágio de vida, que a faça evoluir moralmente, amadurecer com experiências benéficas. Na verdade Luísa se deixa conduzir, influenciar e atribui aos outros a responsabilidade pelo desencadear de suas vivências, mais parece uma figura decorativa. Porém, na crítica queirosiana, pode-se constatar que as barreiras sociais, que definiam o modo de vida da mulher no século XIX, contribuíam enormemente para a configuração feminina representada pela protagonista da trama. As imposições da sociedade destinadas à mulher iam minando sua capacidade subjetiva de pensamento, de crítica O padrão de comportamento instaurava à figura feminina a condição de mero exemplar de uma espécie, uma vez que restringia o seu potencial, enquanto um ser pensante.

Desse modo, percebe-se que a referida obra queirosiana ilustra fielmente o comportamento da mulher burguesa no século XIX e com isso evidencia o quanto a arte literária era envolvida na afirmação de um perfil social feminino, uma vez que este inibia a ação crítica que a mulher poderia ter diante do que lia. "Mulheres nem sempre leem, ou nem sempre leram, como mulheres: elas foram alienadas de uma experiência condizente com sua condição de mulheres". ${ }^{3}$ Nessa perspectiva, observa-se que a leitura feminina não era uma prática desenvolvida a partir da mulher propriamente, mas sim conforme a ótica masculina, afinal boa parte da literatura da época era produzida por homens, que tinham a oportunidade de sugerir, na obra que criavam, a sua própria mentalidade, reservando à mulher a condição de mera consumidora. A personagem Luísa absorve o padrão feminino estabelecido e isto se reflete na maneira como lê, como se posiciona diante do que lê.

Duarte (1997: 352-354) afirma que Luísa se deixa influenciar por um consumo literário que a "divorciava" de uma realidade insatisfatória, ou seja, ia aos livros para fugir um pouco da vida que lhe era imposta, o que reafirma a sua postura romântica, uma vez que a evasão é uma característica de tal tendência. Mas é importante frisar que a realidade de Luísa a aborrecia por ser diferente daquela lida nos romances e não por ela enxergar todas as limitações sociais que a aprisionavam; seu modo de ler a impedia de ter tal discernimento. Segundo Costa Lima (1983), as pré-concepções de um leitor, ou seja, as marcas culturais atreladas ao meio social e a história pessoal do indivíduo, influenciam a sua compreensão e podem, inclusive, direcionar a sua leitura, "impondo-se" ao texto. Mas, logicamente, cabe ao leitor permitir que tais condicionamentos apenas influenciem a sua percepção, mas não a ponto de defini-la. Um processo de leitura pressupõe a participação do leitor, como um "agente distinto" ${ }^{32}$ e não de maneira passiva, apenas recebendo informações e ideias.
32. COMPAGNON. O demônio da eoria: literatura e senso comum, p. 145. 
Em O primo Basilio, observa-se que as circunstâncias sociais interferem no modo de ler de Luísa, de maneira determinante, o que a restringe a uma mera consumidora de romances.

Assim, evidencia-se que a partir da ficção queirosiana é possível observar, de maneira representativa, uma forma de recepção de textos literários em que uma leitora se identifica sobremaneira com determinados estilos, a ponto de deixá-los influenciarem sua própria vida. A partir da personagem Luísa, Eça de Queirós faz severa crítica à sentimentalidade e à idealização românticas, presentes nas leituras por ela realizadas, numa possível tentativa de denunciar as absurdas limitações do universo feminino, uma vez que a mulher não conseguia estabelecer um distanciamento crítico, diante do que lia, afinal, seu comportamento de leitura estava atrelado ao seu perfil social bastante limitado e retrógrado.

Repudiando o reinado da arte enquanto mero entretenimento banal, os realistas, a exemplo de Eça, pregavam a arte comprometida com a solução dos problemas humanos aliando-se para tanto à ciência. Acreditavam que a literatura devesse estar a serviço das causas transformadoras do indivíduo em sociedade e não da confissão de vagos estados de alma. À criação literária, portanto, correspondia uma função social, esta assertiva é claramente visível nas obras realistas, a exemplo de $O$ primo Basílio, em que tal intuito se fundamenta, entre outros aspectos, numa denúncia acerca de drásticas imposições sociais relativas à mulher e verificadas, no caso de Luísa, a partir do seu comportamento de leitura. Tornou-se possível perceber também a relação entre a arte literária e os pressupostos culturais, uma vez que ela revela a desigualdade da mulher numa sociedade que não permitia sua ascensão intelectual. Tal situação podia ser entrevista mediante as possibilidades de leitura que eram tipicamente femininas, bem como através do posicionamento que a mulher tomava diante do que lia.

Observa-se também a associação entre a leitura literária feminina e a consolidação de valores sociais que muito contribuíam para a condição de inferioridade atribuída à mulher. A composição de Luísa representa o alcance que pode ter a obra literária, no sentido de influenciar comportamentos, considerando o contexto da época. Além disso e, principalmente, torna-se viável a participação da literatura, no levantamento de reflexões críticas, a partir da representação feminina ali expressa, seja no tocante ao processo evolutivo por que passou a atuação social da mulher, se comparado o século XIX com a atualidade, ou ainda para perceber como habilidades de leitura associam-se à emancipação do indivíduo, no sentido de torná-lo livre para desenvolver suas próprias ideias, sem uma restrita fidelidade a padrões estabelecidos. A personagem Luísa não desenvolveu tal capacidade e acabou por viver presa aos moldes instituídos para a mulher. 
De posse dessas ideias, o leitor de $O$ primo Basílio pode ampliar a sua mundividência, o que de certa maneira reafirma os pressupostos da estética realista, que instituem a proximidade entre arte e meio social. Convém considerar, entretanto, que os efeitos de leitura advindos de uma criação artística literária estarão sempre na dependência das particularidades subjetivas do leitor, da sua capacidade de percepção. Esta leitura da referida obra queirosiana, em que se analisa uma personagem leitora e as implicações relacionadas ao seu modo de compreensão, só foi viável devido à captação prévia das críticas do autor ao romantismo e, principalmente, da censura ao universo feminino burguês oitocentista. Sem a percepção de tais informações, as ideias acerca do romance talvez se limitassem ao enredo e às ações das personagens, mas a obra de Eça dá margens a uma leitura muito mais ampla, pois há aspectos diversos a serem explorados, especialmente no que se refere às representações de personagens leitores.

Considerando o caso da protagonista de O primo Basílio, evidencia-se que à prática de leitura feminina correspondia uma imposição de valores culturais que distanciavam a mulher de qualquer percepção crítica, tornando-a passiva e bastante influenciável. Por outro lado, muito além da mera representação, a obra permite a compreensão de que a leitura literária tem grande potencial significativo, que pode ser notado de modo sensato e crítico. Afinal, ler a literatura compreende um processo de percepção do mundo e de suas infinitas possibilidades. "Práticas de leitura englobam também uma dimensão simbólica, dado que a leitura - inclusive e, talvez sobretudo, a literária - influencia atitudes, comportamentos, valores, e crenças de quem lê". ${ }^{33}$ Porém, tal influência pode atuar de modo crítico, em que se considerem os contextos envolvidos; mas não foi essa a dinâmica de leitura de Luísa.

\section{REFERÊNCIAS}

ABREU, Márcia. Prefácio a O livro e a leitura em Eça de Queirós. Florianópolis: Escritório do Livro, 2007, p. 15-21.

ASSIS, Machado de. Crítica literária.

Obras completas de Machado de Assis. Rio de Janeiro: W.M. Jackson, 1962, p. 154-79.

BELLINE, Ana Helena Cizotto. Leituras de Luísa. Encontro Internacional de Queirosianos: 150 anos com Eça de Queirós, 3., 1997. São Paulo. Anais do III Encontro Internacional de Queirosianos: 150 anos com Eça de Queirós. São Paulo: USP, 1997, p. 521-26.

CHARTIER, Roger. A aventura do livro: do leitor ao navegado São Paulo: Editora Unesp, 1999

COMPAGNON, Antoine. $\mathbf{O}$ demônio da teoria: literatura e senso comum. Belo Horizonte: Ed. UFMG, 2006.
33. LAJOLO. Anais do III Encontro Internacional de Queirosianos: 150 anos com Eça de Queirós, p. 15. 
COSTA LIMA, Luiz. Hermenêutica e abordagem literária.

Teoria da literatura em suas fontes. Rio de Janeiro: Francisco Alves, 1983, v. I, p. 52-83.

CULLER, Jonathan. Teoria literária: uma introdução. São Paulo: Beca, 1999.

CULLER, Jonathan. Lendo como mulher. Sobre a

desconstrução - teoria e crítica do pós-estruturalismo. Rio de Janeiro: Rosa dos Tempos, 1997, p. 52-77.

DA CAL, Ernesto Guerra. Língua e estilo de Eça de Queirós. Rio de Janeiro: Tempo Brasileiro, 1969.

DAL FARRA, Maria Lúcia. Eça educador e aprendiz. Prefácio a $\mathbf{O}$ primo Basílio. São Paulo: Ática. 2004, p. 3-10.

DANTAS, Francisco José Costa. A mulher no romance de Eça de Queirós. São Cristóvão: Ed. UFS, 1999.

DUARTE, Maria do Rosário da Cunha. A inscrição da leitura na ficção queirosiana: O primo Basílio. Encontro Internacional de Queirosianos: 150 anos com Eça de Queirós, 3., 1997, São Paulo. Anais do III Encontro Internacional de Queirosianos: 150 anos com Eça de Queirós. São Paulo: USP, 1997, p.348-54.

JAUSS, Hans Robert. A estética da recepção: colocações gerais JAUSS, Hans Robert. [et al]. A literatura e o leitor: textos de estética da recepção. Rio de Janeiro: Paz e Terra, 1979, p. 43-61.
LAJOLO, Marisa. Eça de Queirós e suas leitoras malcomportadas. Encontro Internacional de Queirosianos: 150 anos com Eça de Queirós, 3. 1997. São Paulo. Anais do III Encontro Internacional de Queirosianos: 150 anos com Eça de Queirós. São Paulo: USP 1997, p. 438-45.

SACRAMENTO, Mário. Eça de Queirós, uma estética da ironia Coimbra: Coimbra, 1945

QUEIRÓS, Eça de. As meninas da geração nova em Lisboa e a

educação contemporânea. Uma campanha alegre. Porto: Porto: Lello \& Irmão, 1946, v.2 p. 105-32.

QUEIRÓS, Eça de. O primo Basílio. São Paulo: Ática, 2004. 